\title{
IAMJ
}

INTERNATIONAL

AYURVEDIC

MEDICAL JOURNAL

\section{ROLE OF VIRECHANA KARMA \& MADHUTAILIKA BASTI IN THE MANAGEMENT OF EKAKUSHTA}

\author{
Shubha C ${ }^{1}$, Amanda Kittie Kynshikhar ${ }^{2}$, Pooja B A ${ }^{3}$, Sangamitra Pattnaik ${ }^{4}$, Abhishek Biswas ${ }^{5}$ \\ ${ }^{1}$ Intern at Sushrutha Ayurvedic Medical College and Hospital, Bangalore, Karnataka, India \\ ${ }^{2}$ Intern at Sushrutha Ayurvedic Medical College and Hospital, Bangalore, Karnataka, India \\ ${ }^{3}$ Associate professor, dept of panchakarma, Sushrutha Ayurvedic Medical College and Hospital, Bangalore, \\ Karnataka, India \\ ${ }^{4} \mathrm{HOD}$ of Panchakarma, Sushrutha Ayurvedic Medical College and Hospital, Bangalore, Karnataka, India \\ ${ }^{5} \mathrm{RMO}$ at Sushrutha Ayurvedic medical college \& hospital, Bangalore, Karnataka, India
}

Corresponding Author: shubhachandrashekhar06@gmail.com

\section{https://doi.org/10.46607/iamj15p5052021}

(Published online: July 2021)

Open Access

(C) International Ayurvedic Medical Journal, India 2021

Article Received: 17/06/2021 - Peer Reviewed: 03/07/2021 - Accepted for Publication: 03/07/2021

\section{Check for updates}

\begin{abstract}
A Hindu female patient of age 30 yrs. with a history of dry scaly white patches over the skin since childhood with prevailing signs of swelling wounds over the patches on the right foot and left palm for six months, diagnosed as a case of Psoriasis came for treatment at Sushrutha Ayurvedic Medical College \& Hospital, Bangalore. Considering the signs and symptoms patient was treated in the line of Ekakustha. Classical Virechana Karma followed by Shamana Aushadhi and Madhutailika Basti was administered. Significant relief was found in the signs and symptoms with no recurrence after the treatment.
\end{abstract}

Keywords: Ekakushta, Psoriasis, Classical Virechana, Madhutailika Basti, Shamana Aushadhi.

\section{INTRODUCTION}

Psoriasis is an inflammatory and proliferative disease of the skin that results in a rapid turnover of the skin cells. The turnover of cells can rise to seven times the normal rate, leading to thickening of the superficial layers of the skin. The ${ }^{1}$ prevalence is approximately $2 \%$ in the European population. Accurate figures for 
many other parts of the world are not available but there seems to be consistent evidence that the prevalence of psoriasis is lower in people of African origin and lower still in some Asian communities such as Japanese. The most characteristic lesions consist of sharply demarcated, dull red or salmon-pink thickened patches with silvery scales. The extensor surfaces of the limbs (especially the elbows, knees, and shins), scalp, and lower back/buttocks are particularly affected, but psoriasis may involve any part of the body. When psoriasis involves the groins, armpits, perineum and the area under the breasts, the lesions tend to be less scaly and rather shiny. The disease is highly variable in duration and extent, and there are several common morphological variants. Contrary to popular belief, up to 50 per cent of affected patients experience significant itch, especially on the scalp and lower legs. Based on the clinical signs and symptoms it can be correlated to Ekakustha ${ }^{2}$. Ekakustha is the skin disease among the Kshudra kustha which has symptoms of aswedanam (not perspire), mahavastu (extensive), yana matsyoshakalalopamam (looks like fish scale) and aruna varna (discolouration).

\section{Case Report}

A 30 yrs. old female patient having itchy, dry, and scaly white patches since childhood with prevailing signs of swelling wounds over the patches on the right foot and left palm from last six months, visited the outpatient Department of Panchakarma, Sushrutha Ayurvedic Medical College \& Hospital, Bangalore. History of present illness reveals that the patient has been diagnosed with Psoriasis since childhood and she noticed pain, bleeding, pus formation and itching spreading over other parts of the body even after taking allopathic medications. She noticed the severe spreading of the whitish discolouration over the elbow crease and abdomen in the last six months. For the same she consulted with the Department of Panchakarma, Sushrutha Ayurvedic Medical College \& Hospital, Bangalore and underwent Virechana Karma followed by Shamana aushadhi and Yoga Basti. Refer Table 1.

\section{Treatment Given:}

The patient was planned for -

1. Classical Virechana Karma

2. Shamana Aushadhi

3. Yoga Basti

\section{Preparation of Panchakarma procedures}

\section{Classical Virechana Karma}

The following steps were followed in the treatment procedure:

- Deepana and Pachana chikitsa

- Snehapana

- Virechana yoga administration

- Samsarjana krama

\section{a. Deepana and Pachana Chikitsa}

Deepana and Pachana chikitsa (medicine that augments and assist the process of digestion) Chitrakadi vati - 2 tablets three times a day, with Lukewarm water for the first 2 days and Agnitundi vati Dose - 2 tablets three times a day, with Lukewarm water for the next 3 days.

\section{b. Snehapana (Administration of medicated Ghee)}

After Deepana Pachana, Snehapana with Mahatiktaka gritha ${ }^{2}$ (medicated Ghee) was given to the patient in increasing order for 2 days, with a dose of $30 \mathrm{ml}$ on $1^{\text {st }}$ day and $100 \mathrm{ml}$ on the $2^{\text {nd }}$ day followed by Lukewarm water.

On the $2^{\text {nd }}$ day of Snehanapana, Samyaka Snehana Lakshana (features of adequate oleation, like producing proper movement of Vata, loose and fatty stools and increase in appetite) were observed. Snehapana stopped on the $2^{\text {nd }}$ day, Sarvanga Abhyanga (a wholebody oil massage) and svedana (a mild steam bath) were given for the next 4 days with Virechana Yoga on the $4^{\text {th }}$ day.

Diet during Vishrama Kala: During the first 3 days of Sarvanga Abhyanga and svedana, ganji diet was advised to the patient.

\section{c. Virechana Yoga}

$40 \mathrm{~g}$ of Trivrit lehya (Operculina turpenthum paste) and $150 \mathrm{ml}$ of Triphala Kashaya (decoction) was administered at 9:00 am on empty stomach. The patient was advised to take Luke in warm water. Observations of Virechana Yoga: 
No. of Vegas (urges of defecation) produced: 14 It was observed as Kaphant Virechana (ended with yellowish thick liquid stool).

\section{d. Samsarjana krama}

Considering the Madhyama Suddhi (moderate cleansing), the patient was advised to take classical Samsarjana karma (specific light diet) for the next 5 days which contains Ganji, khichdi, rice and dal.

\section{Shamana aushadhi:}

The following aushadhis were given in the treatment procedure along with warm water for 15 days:

- Mahatiktaka gritha Gel capsule - 1 tablet (Morning and Night, A/F)

- Gandhaka rasayana - 1 tablet (Morning and Night, A/F)

- Arogyavardhini vati - 1 tablet (Morning and Night, A/F)

- Mahamanjista kwatha - 10ml (Morning and Night, B/F)

Follow up: 18 days

Results: The following results were observed after the Virechana Yoga and Shamana aushadhi treatment was given:

1. Itching reduced

2. Patch and dryness reduced

3. Bleeding stopped
But the patient still noticed signs of swelling wounds over the Psoriasis patches on the right foot and left palm.

\section{Yoga Basti:}

The patient visited the department after 18 days for follow-up and was advised to undergo Yoga Basti. Madhutailika ${ }^{3}$ Niruha Basti and Anuvasana Basti were given. One course of Yoga Basti was administered for 8 days, during this period Stanika Abhyanga and Swedana were given which are a part of Purvakarma for Basti.

\section{Preparation and dosage of Niruha and Anuvasana} Basti:

Niruha Basti: The preparation of Niruha Basti is based on Madhutailika Basti.

Dose of Niruha Basti

- Makshika-100 ml

- Saindhava Lavana - 6 gm

- Mahatiktaka ghrita $-100 \mathrm{ml}$

- Shatapushpa-6 gm

- Nimba churna-6 gm

- Eranda Moola Kwatha - $200 \mathrm{ml}$

- Madanphala-6 gm

Dose of Anuvasana Basti

- Gandharvahastadi taila $-50 \mathrm{ml}$

- Guggulu tiktaka gritha ${ }^{5}-50 \mathrm{ml}$

- Saindhava and Shatapushpa - 5 gm

Table 1: Showing the details of Basti Administration and Pratyagamana kala on each day.

\begin{tabular}{|l|l|l|l|l|l|l|l|l|}
\hline Day & 1 & 2 & 3 & 4 & 5 & 6 & 7 & 8 \\
\hline Type of Basti & Anuvasana & Niruha & Anuvasana & Niruha & Anuvasana & Niruha & Anuvasana & Anuvasana \\
\hline Retention Time & 8min & 10min & 8hrs40mins & 10mins & 6 mins & 13mins & 8hrs & 5hrs \\
\hline
\end{tabular}

Results: The following results were observed after the Yoga Basti treatment was given:

1. Swelling reduced

2. Itching reduced

3. Patch and dryness reduced

To date, there is no relapse in the symptoms. The patient is still in the follow-up and is being administered for the following aushadhis under Shamana aushadhi treatment for 1 month:

- Mahatiktaka gritha Gel capsule - 1 tablet (Morning and Night, B/F)
- Gandhaka rasayana - 1 tablet (Morning and Night, B/F)

- Gopichandanadi vati - 1 tablet (Morning and Night, A/F)

- Gorochanadi vati - 1 tablet (Morning and Night, $\mathrm{A} / \mathrm{F})$

- Khadirarishtai - 3 spoons with equal quantity of water (Morning and Night, A/F)

- Mahamarichyadi taila - External application 
Follow up: 3 months

Table 2: Showing the psoriasis area and severity index score.

\begin{tabular}{|l|l|l|}
\hline \multicolumn{2}{|l|}{ Psoriasis Severity Index Score } & 0 \\
\hline 1 & Scalps and hairline & 0 \\
\hline 2 & Face, Neck and Ears & 0 \\
\hline 3 & Arms and armpits & \pm \\
\hline 4 & Hands, fingers and fingernails & 0 \\
\hline 5 & Chest and abdomen & 0 \\
\hline 6 & Back and shoulders & 0 \\
\hline 7 & Genital area and/or around the anus & 0 \\
\hline 8 & Buttocks and thighs & \pm \\
\hline 9 & Knees, lower legs and ankles & +
\end{tabular}

The current average severity of Psoriasis: 5 (Intensely inflamed skin with/without postulation)

Overall state of Psoriasis: 3 (Moderately severe with obvious redness, scaling or thickening)

\section{DISCUSSION}

In Ayurveda, all the skin disorders have been mentioned under one umbrella- Kushta. Looking into signs \& symptoms, specially Dosha-Dushya Samuthana in can be considered as Eka Kushta parallel in Allopathic science as Psoriasis. As per classical reference, (a) In Bahu-Dosha Avastha Nitya Virechana is indicated. (b) Punah-Punah Shodhana in Kushta. (c) Virechana is the $1^{\text {st }}$ line of treatment for Pitta \& Raktaja Vyadhi. Hence, Virechana was administered. Chitrakadi Vati \& Agnitundi Vati used in DeepanaPachana having ingredients of Katu Rasa dominance which helps in Ama-Pachana \& Agnideepana. Mahatiktaka Ghrita was given for Abhyantara Snehapana. As abhyantara snehapana is contraindicated in Kushta but, as a prerequisite before virechana karma, snehapana is mandatory. As per literature in that case tikta sadhita dravya snehana administration has been specified. In Charaka Samhita, while explaining Kushtachikitsa, it is mentioned as "Virechanam cha agrey". Hence using trivrit lehya virechana was administered. as it helps to eliminate vikrita pitta along with another Dosha.

According to Acharya charaka basti is contraindicated in kushta but based on avastha Basti can be administered. Hence in this present case looking into the symptoms, Basti treatment was also planned and also skin lesion was more in the lower part of the body, as Acharya Sushrutha also mentions if the lower part of the body is affected, Basti is the treatment of choice. Madhutailika Basti was administered in the form of yoga basti protocol. Though Basti is contraindicated in Kushta, Acc. Sushrutha Acharya, "basti vate cha pitte cha kaphae rakte cha sashyate; samsarge sannipate cha bastireva hita sada" ", basti is useful in disorders of tridosha. In this case pitta pradhana, tridosha involvement was observed. Hence after the treatment, significant improvement was seen. After treatment through significant improvement was observed, to prevent the reoccurrence following shamanaushadhi was administered as a part of Vyadhiprathyanika Chikitsa.

\section{CONCLUSION}

According to Ayurveda Kushta is considered as one among bahudosha avastha vyadhi where repeated samshodhana is required. The signs \& symptoms can be compared to Psoriasis in Allopathic Science, which is widespread chronic, frequently re-occurring disease of the skin in the present era. Based on the doshic predominance, Virechana karma was given to eliminate the vitiated pitta. Further, shamana aushadhis were advised, followed by Basti karma. Thus, this treatment was found to be efficacious in the management of the present clinical case of Kushta. 


\section{REFERENCES}

1. Davidson's principle \& practise of medicine, $22^{\text {nd }}$ edition, 2014, published by Churchill Livingstone publication, chapter no. 28, Skin Disease, page no. 1287.

2. Agnivesha, Charaka samhita, Ayurveda deepika commentary by chakrapani data, $7^{\text {th }}$ chapter, Kushtachikitsa adhyaya, verse no. $21 \& 150$, published by Chaukambha orientalia, Varanasi; $2^{\text {nd }}$ edition, the year 2000; page no.151-157.

3. Sushruta, Sushruta Samhita, edited by Vaidya Yadavji Trikamji Acharya \& Narayan Ram Acharya, published by Chowkhambha krishnadas Academy, Varanasi, reprinted in 2004; Chikitsa sthana 38/114, Page no. 548.
4. Govinddas, Bhaisajya ratnavali, Vriddhirogachikitsa prakaran 43/105-108, Hindi commentary by Ambikadatta shahstri, Chaukhambha Sanskrit sansthan; Varanasi, 20th edition, 2010.

5. Vagbhatta, Ashtanga hridaya with sarvanga sundara commentary, edited by Harishashtri Paradkar, published by Chaukambha orientalia, Varanasi, $7^{\text {th }}$ edition, 1982; page no.726-728.

6. Sushruta, Sushruta Samhita, edited by Vaidya Yadavji Trikamji Acharya \& Narayan Ram Acharya, published by Chowkhambha krishnadas Academy, Varanasi, reprinted in 2004; Chikitsa sthana 35/6, Page no. 525.

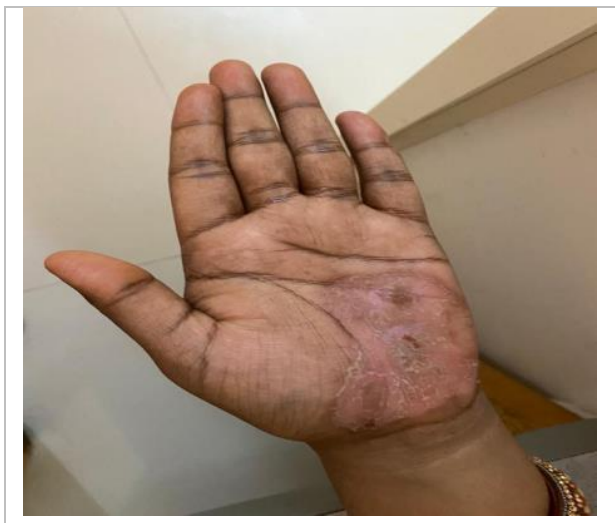

Fig 1.a. Before treatment

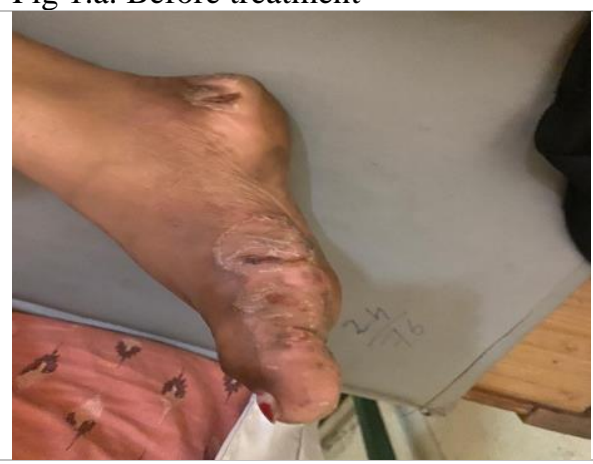

Fig.2b. After treatment

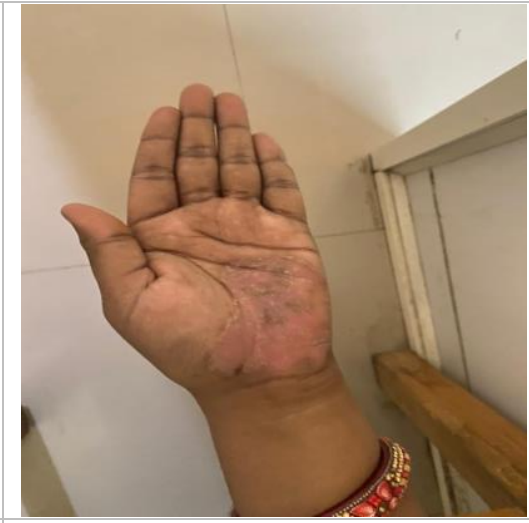

Fig.1b. After treatment

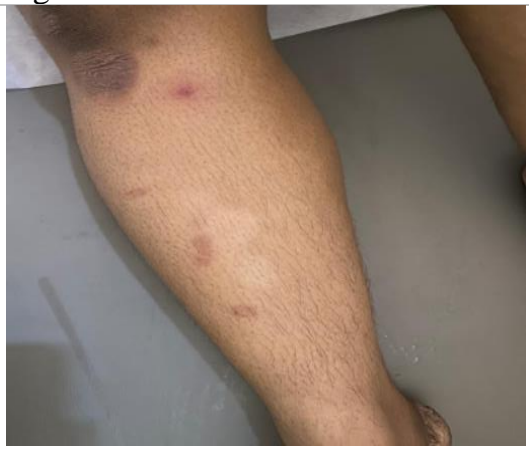

Fig.3a. Before treatment

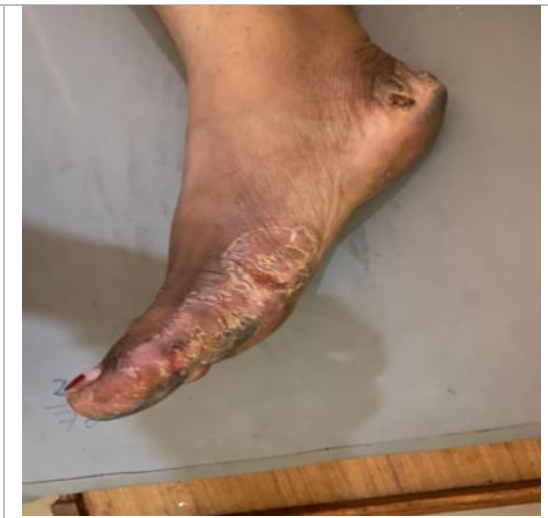

Fig.2a. Before treatment

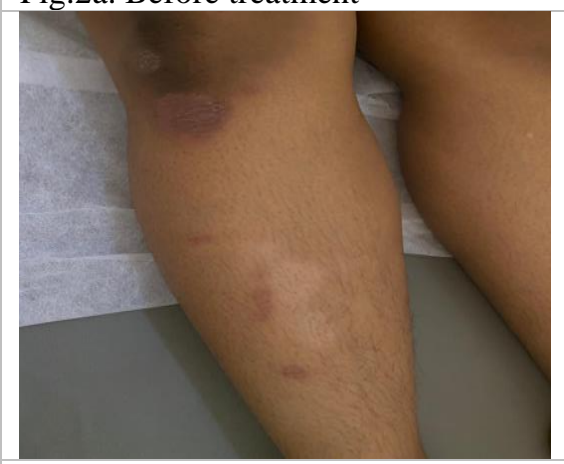

Fig.3b. After treatment

\section{Source of Support: Nil Conflict of Interest: None Declared}

How to cite this URL: Shubha C et al: Role Of Virechana Karma \& Madhutailika Basti In The Management Of Ekakushta. International Ayurvedic Medical Journal \{online 2021 \{cited July, 2021\} Available from: http://www.iamj.in/posts/images/upload/3050 3054.pdf 